\title{
WRONGFUL LIFE CLAIMS UNDER SOUTH AFRICAN LAW: AN OVERVIEW OF THE LEGAL FRAMEWORK
}

\section{Introduction}

Is there any probability that life can be an injury? This is a piping-hot debate among lawyers, doctors, academics, theologians, philosophers, and all affected as well as interested parties. Wrongful birth and wrongful life claims are often challenged all over the world. It is important to draw a clear distinction between wrongful birth and wrongful life claims. Wrongful birth claims are defined as prenatal negligence claims brought, by the parents of a child who is born with birth defects or abnormalities, against a doctor who negligently failed to identify, diagnose, or inform the parents of the child about possible birth defects or abnormalities. By contrast, wrongful life claims are defined as prenatal negligence claims that are brought on behalf of the child who is born with birth defects or abnormalities, against a doctor who negligently failed to identify, diagnose, or inform the parents of the child about possible birth defects or abnormalities (Burns "When Life is an Injury: An Economic Approach to Wrongful Life Lawsuits" 200352 Duke LJ 807). The core of both claims is that, were it not for the misconduct of the defendant (the doctor), the child would not have been born.

Moreover, the existence of wrongful birth claims can be based on two realities, namely medical and legal realities. The medical reality relates to the existence and presence of modern, state-of-the-art technology that enables doctors to identify and diagnose children with birth defects or abnormalities before birth. The legal reality is that such claim would make no sense and would be impossible without lawful access to termination of the pregnancy (that is, abortion) - otherwise, how could the wrongful birth have been prevented (Duncan 'Statutory Responses to 'Wrongful Birth' and 'Wrongful Life' Actions" 200414 Life and Learning XIV 3 3-4)?

In South Africa, if parents are informed that there is a possibility that their child will suffer from a serious medical condition or a congenital disability (birth defects or abnormalities), the mother has a choice not to give birth to the child and to terminate the pregnancy in terms of section 12(2)(a) of the Constitution and under the Choice on Termination of Pregnancy Act 92 of 1996. This means that wrongful birth claims under South African law are possible, since the parents of a child born with birth defects or abnormalities are entitled to claim patrimonial damages in circumstances where a doctor negligently failed to give the necessary medical advice. However, the position regarding wrongful life claims is different, and South African law has denied any wrongful life claims, which means that a child, after being born with birth defects or abnormalities, cannot institute a claim based on wrongful life. 
Wrongful life claims are a controversial issue, not only in South Africa, but also worldwide; hence the aim of this analysis is, firstly, to give an overview of current case law in South Africa, and of how wrongful life claims are currently dealt with. Thereafter, the most recent case, $H$ v Fetal Assessment Centre, will be discussed, as well as the different schools of thought, the positions in England, Germany and the Netherlands, and some possibilities as to what the situation pertaining to wrongful life claims may be when the High Court decides on the recognition or non-recognition of wrongful life claims.

\section{Current case law in South Africa}

The cases of Friedman $v$ Glicksman (1996 (1) SA 1134 (W)) and Stewart $v$ Botha (2008 (6) SA 310 (SCA)) are currently the benchmarks against which wrongful life claims are measured in South Africa.

\section{Friedman $v$ Glicksman}

In the Friedman case, the action was brought by the mother of a child who was born with severe physical disabilities, against a specialist gynaecologist who, allegedly had negligently failed to inform the mother that there was a high probability that her child would be born with severe physical disabilities. The mother asserted that, had she been properly informed by the specialist, she would have chosen to terminate the pregnancy. The mother claimed, in her personal capacity, for expenses pertaining to the maintaining and upbringing of her disabled child. This included expenses for future medical treatment, as well as other special expenses pertaining to the child. This claim was based on wrongful birth, which is recognised under South African law, and there were no issues regarding this claim. However, the mother also brought a claim on behalf of the disabled child, claiming for general damages for pain and suffering as well as for loss of future income. This claim was based on wrongful life, which is not recognised under South African law. The court in this case held that a claim for wrongful life was not possible, based on the following reasons: firstly, such a claim would be contrary to public policy as well as the feelings and views of the community; secondly, such a claim would establish a precedent for disabled children to sue their parents because their parents may have allowed them to be born while being aware of the risks of the children being born with birth defects or abnormalities (severe physical disabilities); and, thirdly, the doctors were not to blame for the child's severe physical disabilities and, because of this, the only legal measure of damage would be the difference in value between the non-existence of the child and the existence of the child with disabilities (1140-1142).

\section{Stewart $v$ Botha}

In the Stewart case, the action was brought by the parents of B who had been born with severe physical disabilities. The first plaintiff, B's mother, claimed in her personal capacity in contract, alternatively in delict, for damages in the amount of R2.66 million. The claim was based on past and 
future medical expenses due to B's disabilities, expenses pertaining to special schooling/education for $\mathrm{B}$, as well as expenses for the maintenance of $B$ for the rest of his life, which was estimated to be 50 years (par 2 of the High Court judgment; Stewart v Botha 2007 (6) SA 247 (C)). The second plaintiff, B's father, sued in delict in his personal capacity and on B's behalf for damages suffered by $B$ in the amount of R2.41 million with regard to future medical treatment that would be needed due to his disabilities, plus the expenses regarding special tuition and maintenance for the rest of his life (par 3 of the High Court judgment). The defendants excepted to the wrongful life claim and argued that their alleged conduct was not unlawful towards B, since they did not owe the unborn foetus, or B after his birth, any legal duty to advise or inform his parents of the possible deformities and abnormalities. The defendants also argued that the damages claimed were not claims which B could bring, since he did not suffer any ascertainable loss himself. The damages lay with B's parents in their respective personal capacities for the loss suffered by them as the parents of a child born with disabilities. Moreover, the defendants averred that there was no cause of action for wrongful life claims under South African law as alleged by B's parents, since, to allow such a claim, would require a comparison between B's existence in a disabled state and his non-existence, and, thereafter, a quantification of the difference. Lastly, the defendants argued that a wrongful life claim was appalling in law, contra bonos mores and against public policy (par 11 of the High Court judgment; see also par 3 of the Supreme Court of Appeal judgment; and Stewart $v$ Botha 2008 (6) SA 310 (SCA)). The Supreme Court of Appeal referred to several arguments and counterarguments regarding wrongful life claims, but came to the conclusion that the crux of the case was the question whether the particular child (B) should have been born at all (par 28 of the Supreme Court of Appeal judgment). In other words, the main issue in this case was whether a comparison should be made between the existence of $B$ with disabilities and the non-existence of B. The court concluded as follows (par 28 of the Supreme Court of Appeal judgment; for discussions on the Supreme Court of Appeal case; see Mukheibir "Wrongful Life - The SCA Rules in Stewart $v$ Botha (340/2007) [2008] ZASCA 84 (3 June 2008)" 200829 Obiter 515 516-518; and Human and Mills "The Immeasurable Wrongfulness of Being: The Denial of the Claim for Wrongful Life" 20101 Stellenbosch LR 67 70-71):

"The essential question that is asked when enquiring into wrongfulness for purposes of delictual liability is whether the law should recognise an action for damages caused by negligent conduct and that is the question that falls to be answered in this case. I have pointed out that from whatever perspective one views the matter the essential question that a court will be called upon to answer if it is called upon to adjudicate a claim of this kind is whether the particular child should have been born at all. That is a question that goes so deeply to the heart of what it is to be human that it should not even be asked of the law. For that reason in my view this court should not recognise an action of this kind."

The court, therefore, denied a claim for wrongful life. Such a claim is contra bonos mores and the conduct of the medical practitioners was not wrongful. 


\section{$3 \quad$ H v Fetal Assessment Centre (2015 (2) BCLR 127 (CC))}

The Fetal Assessment case is a new case that caused heated debates on whether wrongful life claims should be recognised or not under South African law. It was emphasised in this case that the common law pertaining to wrongful life claims and children's rights might need further development in order to recognise such claims.

One can say that the Fetal Assessment case focuses on the following important aspects: it expounds and elaborates on the rights of a child with regard to a cause of action occurring before birth, and on the Court's responsibility to consider the best interests of the child when developing the common law. Accordingly, this case also gives guidelines on how the common law can be developed in order to recognise wrongful life claims regarding prenatal medical negligence.

\section{Facts}

The core matter in the Fetal Assessment case was whether wrongful life claims should be permitted under South African law (par 1-2). The applicant in this case was a boy who was born with Down's syndrome in 2008. His mother (the plaintiff) instituted a claim on his behalf in the High Court for damages against the respondent, the Fetal Assessment Centre (hereinafter "the Centre"). The claim was based on the alleged misconduct and negligent failure of the Centre to inform the mother that there was a high probability of the child being born with Down's syndrome. It was alleged that, had the mother been informed of the birth defect(s), she would have chosen to terminate the pregnancy. Special damages for past and future medical expenses, as well as general damages for disability and loss of amenities of life, were claimed on behalf of the child. The Centre excepted to the wrongful life claim and averred that such a claim was appalling in law, since it did not disclose a cause of action recognised by South African law (par 3). The exception was based on the assumption that the common law of delict at present does not recognise a claim of wrongful life (par 4). The High Court relied heavily on the decision in the Stewart case and upheld the exception and dismissed the plaintiff's claim with costs (par 5). The mother on behalf of the child then sought leave to appeal directly to the Constitutional Court against the High Court's decision. The mother on behalf of the child argued that an appeal to the Supreme Court of Appeal would be time-consuming, since such court would also rely on the decision in the Stewart case (par 7).

\section{Developing the common law}

The applicant argued that, in the light of the aforementioned facts, the common law should be developed in order to allow wrongful life claims. The Court held that this was an issue of cardinal legal and constitutional importance, since, on the one hand, the prospect of developing the common law pertaining to wrongful life claims might be possible, but, on the other hand, it might also not be possible. The Constitutional Court held that it was 
in favour of allowing the common law to be developed in the High Court and the Supreme Court of Appeal. It also added that the outcome of this appeal would permit the High Court and, if required, also the Supreme Court of Appeal, to play a meaningful and substantial role in the further development of the common law - of course, within the guidelines of the Constitutional Court judgment (par 9).

The Court emphasised the importance of section 39(2) of the Constitution, which stipulates that the "spirit, purport and objects of the Bill of Rights" must be promoted when courts are developing the common law (see the case of Carmichele $v$ Minister of Safety and Security (Centre for Applied Legal Studies Intervening) 2001 (4) SA 936 (CC) par 35). The Court also referred to the cases of $K v$ Minister of Safety and Security (2005 (6) SA 419 (CC)) and $S v$ Thebus (2003 (6) SA 505 (CC)), where the overall purpose of section 39(2) was explained (par 13):

"The overall purpose of section 39(2) is to ensure that our common law is infused with the values of the Constitution. It is not only in cases where existing rules are clearly inconsistent with the Constitution that such an infusion is required. The normative influence of the Constitution must be felt throughout the common law. Courts making decisions which involve the incremental development of the rules of the common law in cases where the values of the Constitution are relevant are therefore also bound by the terms of section 39(2). The obligation imposed upon courts by section 39(2) of the Constitution is thus extensive, requiring courts to be alert to the normative framework of the Constitution not only when some startling new development of the common law is in issue, but in all cases where the incremental development of the rule is in issue."

The Court held that, since the common law did not recognise a delictual claim based on wrongful life, the development of the common law at issue was of the kind where "a common-law rule is changed altogether, or a new rule is introduced". It held, further, that, when there is a need to decide whether the common law should be developed, the following must be taken into consideration: in some cases, there may be appropriate circumstances present where the decision to develop the common law may be decided on exception. In other cases, such a decision should only be made after all the evidence is heard, which means that the decision can then be given "in the light of all the circumstances of the case, with due regard to all relevant factors" (par 14).

The Court pointed out that the legal issue in this case was not the wrongful life of the child as such, but whether the law, with due consideration of constitutional values and rights, should allow a child to claim compensation for a life with disability. It held that the basis for determining the viability of a wrongful life claim in this case lay in the fact that South African law, including the common law, must conform to the values and rights of the Constitution (in the Carmichele case, the Constitutional Court stated that, although the common law did not recognise the plaintiff's claims, society and the boni mores commanded that the position should be changed). Based on the outcome of the aforementioned case, it can be argued that the common law pertaining to wrongful life claims is deficient in its failure to recognise wrongful life claims, and that it should be developed in order to be consistent with the values and rights enshrined in the 
Constitution (Van Niekerk "Wrongful Life Claims: A Failure to Develop the Common Law?" 20123 Stellenbosch LR 527 534-535). The specific values and rights referred to are those of equality, dignity, and children's rights with particular reference to the best interests of children that are of paramount importance in every matter concerning them (par 49). The Court made it clear that, in this case, these rights were applicable to the child at the time of birth (par 50). The Court therefore stated that one of the key role-players in determining whether, or to what extent, a wrongful life claim will be recognised is the kind of legal reasoning permissible in the legal culture or tradition of a country or a country's legal system (par 47).

\section{Criticism of the Stewart case}

The Constitutional Court, in its judgment, expressed criticism of the Stewart case. The Supreme Court of Appeal in the Stewart case came to the conclusion that a claim for wrongful life might only succeed if a court could evaluate the existence of a child in a disabled state against the nonexistence of the child, which is almost impossible (par 21). In other words, this means a comparison between life and non-existence. As a result of this, the Constitutional Court indicated that such a comparison created "insurmountable problems at various stages of the enquiry into the elements or requirements of our law of delict - wrongfulness, causation, foreseeability in negligence and in the quantification of damages" (par 20). The Court went further and stated that, if one says that a medical expert's negligence did no harm to the child, there should be a reason for saying so, and the reason given in our law and in many other jurisdictions is that harm can only be established by comparing existence with non-existence. The consequence hereof is that a value choice is hidden - a choice that is not supposed to be hidden. The Court clearly stated that it is thus of great importance that such a value choice should be openly acknowledged and squarely defended by judges under the South African Constitution (par 22).

The Stewart case was further criticised, since it appeared that insufficient recognition was given to the need to place the viability of the child's claim within the normative framework of the Constitution. It was therefore necessary to examine foreign law, and the Court observed that the denial or non-recognition of wrongful life and wrongful birth claims usually occurs in countries where a woman's right to choose is significantly restricted, or where abortion is prohibited or limited to instances where abortion is the only way to save a mother's life. The Court also stated that it is evident that jurisdictions rejecting such claims are also unsuccessful in recognising the (best) interests of children. The Court noted that the situation differs in countries where a woman's right to choose is restricted to the minimum as well as in judgments where the rights of children are emphasised and protected. In these countries, wrongful life claims are often recognised without difficulties (par 44-46).

Furthermore, the Court stated that the existing common law as espoused by the Supreme Court of Appeal in the Stewart case did not consider whether the recognition of a wrongful life claim would be in the best interests of the child, nor did it take into account the principles of other rights 
contained in the Bill of Rights. The Constitutional Court held that, due to this, a claim for wrongful life may not be inconceivable (par 52).

The Court then turned to an examination of the potential for the recognition of wrongful life claims against the requirements of a delict and stated the following (par 52):

"At first blush it might seem that the best interests of the child should be considered in the enquiry, but this direct engagement with the right of children to expect that their best interests will be considered paramount in any matter that concerns them is said to fly in the face of the generally accepted requirements of our law of delict. That contention needs to be examined carefully in relation to each of those requirements."

\section{Requirements of a delict, and the best interests of the child(ren)}

\section{Harm}

With regard to the requirement of harm, the Court stated that the mother was deprived of the opportunity to make an informed choice to terminate the pregnancy. This was due to the medical expert's negligence in not informing the mother that her child would be born with a congenital disability. In consequence of the medical expert's neglect to inform the mother or parents of this, the child was born in a disabled state, and the parents suffered patrimonial loss in the form of an additional, unwanted financial burden in maintaining the child. It is therefore clear that South African law recognises that the mother or parents have a claim in delict against the medical expert. This is known as a wrongful birth claim. However, recognising a child's claim (wrongful life claim) asks the Court to take a step further. The Court asked what the position would be if the parents failed to institute a wrongful birth claim against the negligent medical practitioner (par 62). It held that, even though the child does not suffer the loss of any constitutionally protected choice, the child will suffer financial loss (harm). This means that there is a probability that a wrongful life claim may be recognised based on the best interests of the child. To put it differently, the medical expert should be liable to the child for the same loss for which he or she would have been liable to the parents (par 63).

\section{Wrongfulness}

Wrongfulness means that there is an infringement of a right and the question of wrongfulness is determined by public policy, which can be found in the values that are treasured in the Constitution. The current and public policy in respect of wrongful life claims can be summarised as follows: "To allow the cause of action would bring into question the value of human life." (Chürr "A Delictual Claim Based on 'Wrongful Life': Is it Possible?" 200972 THRHR 168 172.) However, the Court held that part of the wrongfulness enquiry is to determine whether there has been a breach in respect of a legal duty not to harm the claimant, or whether a breach of the claimant's rights or interests has occurred. Section 28(2) of the Constitution expressly states that the best 
interests of children are of paramount importance in every matter concerning them. The Court stated that this includes the misdiagnosis by a medical expert on prenatal matters that results in the child being born with birth defects or disabilities. When parents do not institute a claim for the medical expenses in the aforementioned circumstances, the loss will befall the child, which means that it would be contrary to the best interests of the child. In other words, the best interests of the child may require that the child should not bear the loss. The Court was of the opinion that it would mean that there may be a legal duty not to cause that loss (par 69). The Court also observed that, in this case, the liability was not indeterminable, but determinable, since either the parents or the child may claim (par 70).

\section{Causation}

The court held that, although the misdiagnosis did not cause the child's disability, the mother would have chosen to terminate the pregnancy had she been aware of the disability. The Court also stated that factual causation might be established, since the misdiagnosis was part of the sequence of events that led to the birth. It held, however, that legal causation may be absent owing to policy considerations, but that this is an issue that can properly be dealt with only when all the facts are known and established at the trial (par 74).

\section{Negligence}

The Court stipulated that negligence will still have to be proved by way of general principles, but that the recognition of a wrongful life claim does not have any effect or influence on the normal application of those principles to the facts of each individual case.

\section{Damages}

The Court found it unnecessary to determine whether the child may have a claim that goes further than patrimonial damages in the form of actual expenses. It held that compensation for intangible loss does not form part of the general principles of Aquilian liability. However, a claim for pain and suffering and for loss of amenities of life is recognised under South African law - this is a special kind of claim which requires the infliction of a bodily injury on the claimant. It also held that there is no need to determine whether the common law requires further development in respect of a child's claim for intangible loss, and also no need to establish the extent or limit of actual patrimonial expenses that may be sought in a child's claim (par 77).

\section{The Court's conclusion}

The Constitutional Court concluded that a child's claim for wrongful life may potentially exist and that the High Court needs to decide whether such claim does exist, and in what form. The High Court must also determine if a wrongful life claim is properly reformulated in delict. In other words, it has to be determined whether a delictual claim based on wrongful life is possible 
under South African law. The Constitutional Court emphasised that this must be done in accordance with the constitutional imperative, which means that the decision must correspond to constitutional rights and values. The best interests of the child should also be taken into consideration (par 81).

\section{Different schools of thought}

There is a wealth of argument concerning the recognition or non-recognition of wrongful life claims, but, despite this, the myriad of arguments can be narrowed down to only "two types", namely those that support the recognition of wrongful life claims and those that are against the recognition of such claims.

Those who support the recognition of wrongful life claims may argue as follows (Feinberg Harm to Others: The Moral Limits of the Criminal Law (1984) 99):

"If you cannot have that to which you have a [birth right] then you are wronged if you are brought to birth. Thus, if the conditions for the eventual fulfilment of the child's future interests are destroyed before he is born, the child can claim, after he has been born, that his rights (his present rights) have been violated. Moreover, if before the child has been born, we know that the conditions for the fulfilment of his most basic interests have already been destroyed, and we permit him nevertheless to be born, we become a party to the violation of his rights."

Those who are against the recognition of wrongful life claims may argue as follows (Steinbock Life Before Birth: The Moral and Legal Status of Embryos and Foetuses 2ed (2011) Chapter 3 par IV):

"It is impossible for a person to be better off never having been born. For if I had never been born, then I never was; if I never was, then I cannot be said to have been better off. For to be harmed is to be made worse off; but no individual is made worse off by coming to exist, for that suggests that we can compare the person before he existed with the person after he existed, which is absurd. Therefore, it is logically impossible that anyone is harmed by coming to exist and wrongful life suits are both illogical and unfair in that they require the defendant to compensate someone he has not harmed."

However, for purposes of this analysis, it is also necessary to set out the reasons why there are arguments against and in favour of wrongful life claims.

\section{Impossibility of calculating damages}

One of the main arguments pertaining to wrongful life claims is that it is impossible to calculate damages in the circumstances. However, in different circumstances, courts have not had difficulties in calculating the damages. It is therefore apparent that arguments regarding proof of damages and the calculation of damages necessitate a critical and thorough evaluation. Wrongful life claims are based on the recovery of patrimonial loss in the form of actual expenses which a child has suffered in respect of medical expenses, special schooling and maintenance, as well as compensation for injury to the child's personality interest and for the pain and suffering the 
child has to withstand due to life in a disabled state. The Courts argue that no damage has been suffered, since "the only life ever possible to [the child] was a life in the handicapped state to which he was born". The counterargument is that, if it were not for the negligence of the medical practitioner, the child would not have been born, since the mother would have chosen to terminate the pregnancy. The child (or the child's parents) therefore suffers financial loss, as well as a life with pain and suffering because of the disabilities. It is important to remember that wrongful birth claims are recognised under South African law and that a comparison is made between life in a disabled state and no life. The Courts do not hesitate in these circumstances to determine/calculate damages. Those in favour of wrongful life claims argue that it seems to be irregular for Courts to allow parents to claim damages in wrongful birth "circumstances", but to deny the child the right to damages in wrongful life "circumstances". Moreover, it is argued that, if there is no difficulty in calculating damages in wrongful birth claims, there should also be no difficulty in calculating damages pertaining to wrongful life claims (Human and Mills 20101 Stellenbosch LR 78-80).

\section{Public-policy considerations}

One of the arguments most commonly raised against the recognition of wrongful life claims relates to the significance of emphasising the intrinsic value of human life (Duncan 200414 Life and Learning XIV 3 16). A claim based on wrongful life has not been allowed by South African courts, since the Courts are convinced that such a claim is against public policy. To put it differently, the current position in South African law is that wrongful life claims are not permissible because existence, although with birth defects or disabilities, can never be an injury cognisable at law. It has been said that life - whether in a disabled state or not - is more valuable than non-life. One can therefore say that those who are against the recognition of wrongful life claims will also use the sanctity-of-life argument, which emphasises that life is sacred (see the discussion of the Stewart and Friedman cases above; see also Liu "Wrongful Life: Some of the Problems" 198713 Journal of Medical Ethics 69 70; and Chürr 200972 THRHR 172). Furthermore, it is argued that the Courts lack the competence to make a comparison between deformed existence and non-existence (Burns 200352 Duke LJ 811-812).

However, the counter-argument is that it is too inflexible and rigid to lay down as a matter of principle (and of substantive law) that life in a disabled state can never be worse than non-life. Moreover, it is accordingly also too rigid to argue that a child who is born with birth defects or disabilities can never be an injury. Understood in this way, it means that life can be worse than non-life and that a comparison between life and non-life seems to be innately possible (Liu 198713 Journal of Medical Ethics 70).

The counter-argument with regard to the sanctity of life was also eroded by the Choice on Termination of Pregnancy Act 92 of 1996, as well as in the case of Christian Lawyers Association of South Africa $v$ The Minister of Health (1998 (4) SA 1113 (T) - for a discussion on this, see Chürr 200972 THRHR 172-173; and Boezaart in Boezaart (ed) Child Law in South Africa (2009) 12-15). Moreover, it is argued that it is unjustifiable to disregard the 
sanctity-of-life argument in wrongful birth claims, but to regard such argument in wrongful life cases as being of cardinal importance (Human and Mills 20101 Stellenbosch LR 85).

There are also those who argue that, if a comparison between existence and non-existence needs to be made, it is better to enter into life with mental or physical disabilities than to have a state of non-existence, except possibly in those extreme cases such as severe disability (Liu 198713 Journal of Medical Ethics 70; and see also Blackbeard "Die Aksie vir 'Wrongful Life': To Be or Not to Be?" 199154 THRHR 57 74). In these circumstances, one can come to the conclusion that wrongful life claims should be recognised only in extreme cases/severe disability cases. The question now is: What exactly is meant by "extreme cases" or "severe disability cases" (this will be discussed in paragraph 7 below).

\section{Undermining the dignity of disabled persons}

Those who are against the recognition of wrongful life claims argue that these claims are pernicious, since it seems that the lives of disabled children are worth less than the lives of healthy children. It is argued: "[l]f all life is presumptively valuable, how can we say that what we really mean is that all lives except for the lives of the disabled are presumptively valuable?" (Duncan 200414 Life and Learning XIV 316 - emphasis in the original). Further, it is argued that, especially in a country like South Africa where extra emphasis is placed on the rights of disabled persons as well as on the right to dignity of all persons, the nature of wrongful life claims implies that disabled persons' rights to life and to dignity are in serious jeopardy. The counter-argument to this is that a wrongful life claim is not a reduction of a child's dignity, but rather a claim that acknowledges a child's dignity. Instead, the non-recognition of a wrongful life claim would reduce the dignity of the child, since the child will live his/her life in a disabled state due to the negligence of a medical practitioner merely because of the "non-existence" argument (Mukheibir 200829 Obiter 520). It is therefore argued that a wrongful life claim should be seen as compensation for, inter alia, the encroachment upon a child's right to dignity and bodily integrity. Thus, in these circumstances, it seems that a child's life is seen as an injury and a pecuniary award should therefore be granted in order to remedy the injury based upon principles of what is just and equitable. This can accordingly be done without having to demean or degrade disabled children's lives by favouring no life over life (Human and Mills 20101 Stellenbosch LR 81; Mũriithi "Does the Recognition of Wrongful Life Claims Rely on a Conceptual Error?" 201137 Journal of Medical Ethics 433 436; and see also par 36 of the Fetal Assessment case).

Another counter-argument is that the Children's Act 38 of 2005 specifically makes provision for a disabled child. Section 6(2)(f) states the following:

"All proceedings, actions or decisions in a matter concerning a child must ... recognise a child's disability and create an enabling environment to respond to the needs that the child has." 
The Children's Act goes further and stipulates the following in section 11(1):

"In any matter concerning a child with a disability due consideration must be given to - (a) providing the child with parental care, family care or special care as and when appropriate; (b) making it possible for the child to participate in social, cultural, religious and educational activities, recognising the special needs that the child may have; (c) providing the child with conditions that ensure dignity, promote self-reliance and facilitate active participation in the community; and (d) providing the child and the child's care-giver with the necessary support services."

It is therefore argued that children with disabilities are a priority of the Children's Act and that they should be assisted and supported as much as possible in order to develop their potential, despite their disabilities. Moreover, the recognition of disabled children, as well as the recognition of their special needs and circumstances, promotes and accentuates the human dignity of disabled children (Bosman-Sadie and Corrie A Practical Approach to the Children's Act (2010) 26; and Human and Mills 20101 Stellenbosch LR 87).

\section{Wrongful life claims against mothers for not terminating the pregnancy}

Those who are against the recognition of wrongful life claims argue that such claims would lead to claims against mothers who do not choose to terminate their pregnancies, despite knowing that their children will be born with birth defects or disabilities. The counter-argument to this is that a mother's choice not to terminate a pregnancy will not be characterised as wrongful, since the Choice on Termination of Pregnancy Act stipulates that the right to terminate a pregnancy is given to the mother (Mukheibir 200829 Obiter 520; and see also par 36 of the Fetal Assessment case).

\section{The practice of defensive medicine}

Those who are against the recognition of wrongful life claims argue that to take legal action against a doctor on the basis of wrongful life endangers the health care and medical system and will have emotional, moral, as well as financial consequences for the medical profession (Chürr 200972 THRHR 174). Moreover, it is argued that wrongful life claims may have a negative impact on the attitudes of doctors, who, in order to avoid liability, may be more inclined to advise parents to terminate the pregnancy in cases where a child may be born with birth defects or disabilities. Doctors are not omniscient and cannot guarantee perfect children. There are many situations and circumstances where doctors would not breach the standard of medical care, but children would still be born with birth defects or disabilities. It is also argued that, although a doctor's negligence caused the child to come into being, the doctor's negligence surely did not cause the child to develop and suffer from birth defects or disabilities. To compel doctors to pay damages for conditions they did not cause is thus inappropriate and tactless (Burns 200352 Duke LJ 822). The counter- 
argument to this is that, when a medical practitioner unreasonably advises parents to terminate a pregnancy, such advice could result in liability (Mukheibir 200829 Obiter 520). For example, if a medical practitioner advises in such a way that no other reasonable medical practitioner would have advised, measures can be taken against such medical practitioner based on professional misconduct.

\section{Best interests of the child}

The Court held in the Fetal Assessment case that the best interests of the child pertaining to wrongful life claims should be taken into consideration when deciding whether such claims should be recognised or not. The Constitution and the Children's Act specifically make provision for the best interests of the child. Section 28(2) of the Constitution states that the best interests of a child are of paramount importance in every matter concerning the child. It is argued that the recognition of human rights, combined with the best-interests-of-the-child standard, requires sensitivity and understanding regarding the specific susceptibility of the disabled child and therefore obliges the courts to evaluate a claim based on wrongful life as well as the delictual elements required owing to this perception. There are, however, three factors that are crucial in this regard (Human and Mills 20101 Stellenbosch LR 86).

Firstly, the Constitution lays the basis for a society where democratic values, social justice and fundamental rights prevail. This means that children are also regarded and acknowledged as bearers of human rights. So, it is argued, when a wrongful life claim arises, it should be remembered that the child is a bearer of the right to human dignity (s 10 of the Constitution as well as s 6(2)(b), 11(1)(c) and 11(2)(b) of the Children's Act), the right to bodily and psychological integrity (s 12(2) of the Constitution), and, of course, the right to life (s 11 of the Constitution). The right to life must be construed on a multidimensional level with the aim of also including the right to survival and development (Human and Mills 20101 Stellenbosch LR 86-87).

Secondly, the Children's Act is of vital importance where fundamental rights are concerned. Section 6(1)(b) of the Children's Act states the following:

"The general principles set out in this section guide all proceedings, actions and decisions by any organ of state in any matter concerning a child or children in general."

Section 6(2)(a) stipulates:

"All proceedings, actions and decisions in a matter concerning a child must respect, protect, promote and fulfil the child's rights set out in the Bill of Rights, the best interests of the child standard set out in section 7 and the rights and principles set out in this Act ..."

Section 7(1) states that, when the best-interests-of-the-child standard is required by a provision of the Children's Act, such standard must be applied 
and several factors must be taken into consideration. Moreover, section $7(1)$ should be read with section 28(2) of the Constitution.

Section 9 of the Children's Act goes further and emphasises the bestinterests-of-the-child standard:

"In all matters concerning the care, protection and well-being of a child the standard that the child's best interest is of paramount importance, must be applied."

Thirdly, it goes without saying that the best-interests-of-the-child standard is also protected and treasured as a fundamental right of the child. The case of Minister of Welfare and Population Development v Fitzpatrick (2000 (3) SA 422 (CC) par 17) emphasises the best-interests-of-the-child principle as follows:

"Section 28(2) requires that a child's best interests have paramount importance in every matter concerning the child. The plain meaning of the words clearly indicates that the reach of $s$ 28(2) must be interpreted to extend beyond those provisions. It creates a right that is independent of those specified in s 28(1)."

It was submitted, in this case, that it is vital that the best-interests standard be taken into consideration in wrongful life claims, especially where the wrongfulness requirement pertaining to wrongful life claims is considered. As a matter of fact, there are specific factors of importance when the best interests of the child are taken into consideration, namely any disability a child may have (s 7(1)(h) of the Children's Act), the child's physical and emotional security, as well as the child's intellectual, emotional, social and cultural development. It was therefore argued that, when a Court needs to consider the recognition or non-recognition of a wrongful life claim, specifically with regard to monetary compensation for a child born in a disabled state due to the negligence of a medical practitioner, it is of the utmost importance that the court takes these three factors into consideration. It was furthermore argued that the above provisions, as well as the bestinterests standard, make sufficient provision for developing and enhancing the law in respect of wrongful life claims (Human and Mills 20101 Stellenbosch LR 87-88).

\section{$7 \quad$ The position elsewhere}

Section 39(1)(b) and (c) of the Constitution stipulates that, when the Bill of Rights needs to be interpreted, a court, tribunal or forum must consider international law, and may consider foreign law. Foreign law may therefore be used in order to assist a Court in making decisions on the issues before it. The Court may have recourse to comparative law, but is under no obligation to consider it (par 28 of the Fetal Assessment case). The position with regard to wrongful life claims in England, Germany and the Netherlands will be discussed very briefly: 


\section{England}

Section 1(2) of the Congenital Disabilities (Civil Liability) Act of 1976 denies the recognition of wrongful life claims. Children born after this Act came into force are not permitted to institute a claim based on wrongful life. However, section 1 of this Act permits a prenatal harm claim for a child if such child was born alive but in a disabled state due to the medical practitioner's act which caused the child's disability. Cases of naturally caused disabilities are thus excluded. In the case of McKay v Essex Area Health Authority ([1982] All ER $771(\mathrm{CA})$ ), a claim based on wrongful life was rejected. The Court held, inter alia, that it was impossible to calculate damages, since such a calculation would cause intolerable and insoluble problems (Giesen "Of Wrongful Birth, Wrongful Life, Comparative Law and the Politics of Tort Law Systems" 200972 THRHR 257 263).

\section{Germany}

In Germany, claims based on wrongful life are denied. The German Courts are of the opinion that damages cannot be calculated and that there is no direct responsibility to prevent the birth of a child who will probably be disabled, since human life might appear inconsequential and worthless if such a responsibility were to be accepted. A well-known case in Germany was the 86 BGHZ 240 (1983) case where a woman had Rubella during her pregnancy. The disease was negligently overlooked and, as a result of this, the mother was unable to abort the foetus and a disabled child was born. The court held that wrongful life claims based on the law of delict are not permitted, since there is no infringement of a right of a child. The court highlighted the fact that the medical practitioner did not cause the disability of the child, but only prevented a possible abortion due to a wrongful diagnosis. The court further held that the child should be appreciative to the medical practitioner for being alive. The court also stated that it was impossible to draw a comparison between life and no life. It was also impossible to compare life in a disabled state with not being born at all. The court therefore came to the conclusion that life can never be a legally compensable injury, since recognising such an injury would infringe the interests of all physically and mentally disabled persons (Hashiloni-Dolev $A$ Life (Un)worthy of Living: Reproductive Genetics in Israel and Germany (2007) 122; and see also par 40 of the Fetal Assessment case).

\section{The Netherlands}

In the Netherlands, wrongful life claims are permissible. The well-known Kelly case $(\mathrm{C} 03 / 206 \mathrm{HR} \mathrm{JHM} / \mathrm{RM})$ is of importance. In this case, the court granted the child cost of living, as well as additional costs pertaining to her disabilities and non-pecuniary losses for her suffering. The court stated that a life with disabilities is not worth less than a life without disabilities. Regardless of a person's disabilities, such a person can still have a dignified and honourable life. Non-existence is not better than life in a disabled state, but that does not mean that life in a disabled state is not challenging and 
difficult to deal with. An award by way of damages will enable a child in a wrongful life claim to improve his or her life and living conditions. In this case, life can be a compensable injury (Giesen "The Use and Influence of Comparative Law in 'Wrongful Life' Cases" 20128 Utrecht LR 3539 and 46; and for a detailed discussion on the Kelly case, see Mukheibir "Wrongful Life Claims in the Netherlands - The Hoge Raad Decides - C03/206 HR JHM/RM: case" 200526 Obiter 753-762).

\section{$8 \quad$ Conclusion}

From the above discussion, it is clear that the Constitutional Court in the Fetal Assessment case was of the opinion that there is a possibility that the common law may be developed. This means that there is then a possibility that wrongful life claims may be recognised. The Constitutional Court indicated that the fact that a child is born with disabilities or abnormalities does not mean that such child should be ignored by the law (par 19). It seems that the only conclusion one can come to is that the Constitutional Court is in favour of wrongful life claims and that there must be some sort of compensation for such a child.

However, the Constitutional Court did not decide whether such claims should be recognised or not. It saddled the High Court with the enormous task, that is, to determine whether a delictual claim based on wrongful life is possible under South African law.

There is much speculation about what the High Court may possibly decide. It is submitted that the High Court may decide on one of four possibilities:

Firstly, that wrongful life is recognised under South African law based on the arguments in favour of such claims. The end result would be that life can be a compensable injury. Secondly, that wrongful life claims are still not recognised under South African law based on the arguments in the Stewart case, and that, despite the fact that the Constitution grants the necessary liberty and permission to develop substantiated exceptions to common law rules or even recognise new remedies for violation of rights, the limits of the law of delict will be stretched beyond recognition for harm of this kind to be recognised within its niche. The end result would be that life can never be a compensable injury (see also par 66). Thirdly, that a wrongful life claim can only be instituted if a wrongful birth claim fails or if no claim based on wrongful birth is instituted. In other words, either the parents or the child may claim, not both or cumulatively (see also par 70 of the Fetal Assessment case). Fourthly, that wrongful life claims are recognised, but only in extreme cases or severe disability cases. However, this means that the court would be obliged to give specific guidelines (or definitions) on what is meant by "extreme cases" or "severe disabilities". The question that was asked in 52 above therefore remains unanswered until a court determines the meanings of "extreme cases" and/or "severe disabilities". If these meanings are determined, the end result would be that, in certain (limited) circumstances, non-life can be better than life and existence can be an injury. 
Nevertheless, some are of the opinion that the recognition of wrongful life claims as a cause of action does not lie with the judiciary, but with the legislature. If this view is adopted, it would mean that appropriate legislation needs to be developed in order to provide for these claims - whether in all circumstances or certain (limited) circumstances (Van Niekerk 20123 Stellenbosch LR538).

Whether there are more possibilities and what the High Court will decide remain open questions. However, when the court decides on this issue of cardinal importance, the following should also be taken into account: whether a child has the fundamental right to be born as a whole, functional human being and whether such a claim does not endorse the idea that, if a child is born with a disability, someone is to blame.

In the meantime, we will have to wait and see what the ultimate decision is.

Chrizell Chürr University of South Africa (UNISA), Pretoria 